REFERENCES:

[1] Cools AM, Struyf F, De Mey K, Maenhout A, Castelein B, Cagnie B. Rehabilitation of scapular dyskinesis: from the office worker to the elite overhead athlete. British journal of sports medicine. 2013; 48:675-676.

[2] Williams JJ, Holleman JD, Simel D. Measuring shoulder function with the Shoulder Pain and Disability Index. The Journal of rheumatology. 1995; 22 (4):727-732

Disclosure of Interest: None declared

DOI: 10.1136/annrheumdis-2018-eular.7289

\section{AB1429-HPR KINESIOTAPING MIGHT HELP TO IMPROVE POSTURAL DISPLACEMENTS IN ADOLESCENTS}

E llie, L. Rusu. Faculty of Physical Education, Department of Sports Medicine and Kinesiology, University of Craiova, Craiova, Romania

Background: The optimal posture plays an important role for preventing musculoskeletal problems. The therapeutic effects of kinesiotaping have been shown in forward head posture and rounded shoulder posture in adults previously. ${ }^{1,2}$ However, as to our knowledge, the effect of kinesiotaping on total posture has not been evaluated before in adolescents. Objectives: To investigate the effect of kinesiotaping application on total posture in adolescents.

Methods: Twenty children (11 M/9 F) with postural displacements were enrolled in the study. The postural displacements were evaluated with a mobile application (PostureScreen) which was validated for postural assessment previously. The total scores which were obtained from the anterior view was used for the analysis. Assessments were performed at baseline and $45 \mathrm{~min}$ following the kinesiotaping application. The kinesiotaping application was performed as seen in Figure 1.

\section{Anterior View}

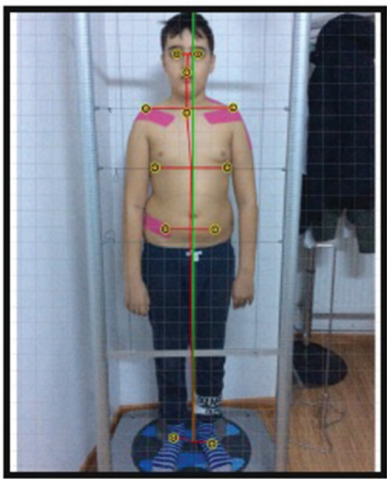

Posterior View

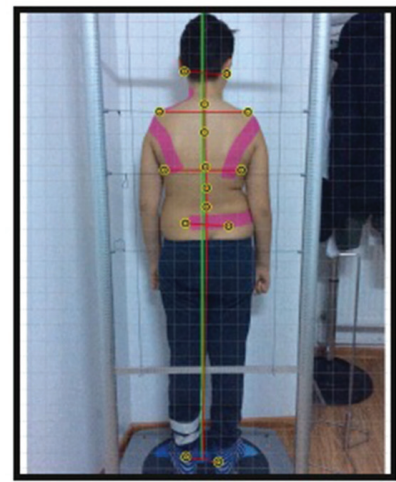

Abstract AB1429-HPR - Figure 1

\section{Right Lateral View}

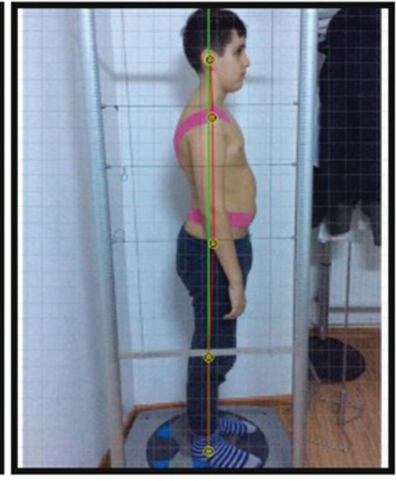

Left Lateral View

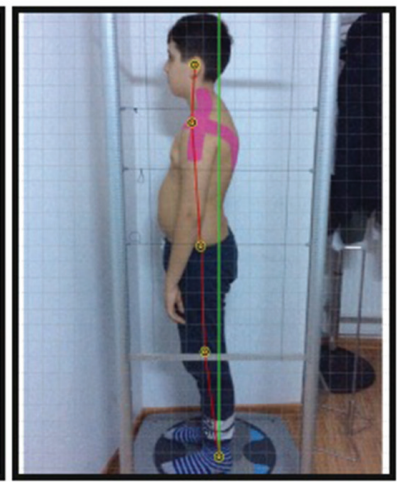

Results: The median age was 12.5 years (IQR: 11.0/15.0 years), the median height was $145.5 \mathrm{~cm}$ (IQR: $142.5 / 166.5 \mathrm{~cm}$ ) and the median weight was $38.0 \mathrm{~kg}$ (IQR: $33.5 / 51.0 \mathrm{~kg}$ ). A significant improvement was observed in anterior angulation degrees. While the baseline score was $8.70^{\circ}$ (IQR: $4.10^{\circ} / 14.55^{\circ}$ ), the score improved following kinesiotaping application to $4.35^{\circ}\left(\operatorname{IQR}: 2.35^{\circ} / 6.30^{\circ}\right) \quad(\mathrm{p}=0.009)$. No significant changes were detected in anterior translation, lateral translation and lateral angulation parameters ( $p>0.05$ )

Conclusions: According to our results kinesiotaping has a potential to improve postural displacements in adolescents. The improvement in the posture might be resulted from a sustained feedback on the trunk by the kinesiotaping. However, future longitudinal studies which are mainly focused on the chronic effect of kinesiotaping are needed to reveal the real potential of kinesiotaping on the postural displacements in adolescents.

\section{REFERENCES:}

[1] Shih HS, Chen SS, Cheng SC, Chang HW, Wu PR, Yang JS, Lee YS, Tsou JY. Effects of Kinesio taping and exercise on forward head posture. J Back Musculoskelet Rehabil 2017;30:725-33.

[2] Gak HB, Lee JH, Kim HD. Efficacy of kinesiology taping for recovery of dominant upper back pain in female sedentary worker having a rounded shoulder posture. Technol Health Care 2013;21:607-12.

Disclosure of Interest: None declared

DOI: 10.1136/annrheumdis-2018-eular.5863

\section{AB1430-HPR EFFECTIVENESS OF FUNCTIONAL RIGID TAPING ON PAIN, FUNCTION AND KINESIOPHOBIA IN PATIENTS WITH LOW BACK PAIN}

F.M Kavak ${ }^{1}$, B. Kavak ${ }^{1}$, E. Tonga ${ }^{2} .{ }^{1}$ Acıbadem University, Atakent Hospital, Acıbadem University, ${ }^{2}$ Marmara University, Faculty of Health Sciences, Department of Physiotherapy and Rehabilitation, Marmara University, Istanbul, Turkey

Background: A small number of studies in the literature suggest that rigid bands applied with different techniques in different regions are effective treatment techniques. On the other hand, there is no study of how rigid bands are effective in the treatment of acute and subacute lumbar pain.

Objectives: Purpose of this study is to determine the efficiency of func tional tape application to patients with acute or subacute low back pain. Methods: 40 patients with acute-subacute low back pain were divided into two groups: control and experimental group. To control group McKenzie exercises, Transcutaneous Electrical Nerve Stimulation (TENS), Hot Pack (HP) and pulsed ultrasound treatments were applied. To experimental group, functional taping were applied in addition of these treatments. Range of Motion (ROM), Visual Analogue Scale (VAS), Tampa Scale of Kinesiophobia (TSK) and The Oswestry Disability Index (ODI) were evaluated pre- and post-treatment and datas were analysed with statistical methods. In analysis; $p$ value was accepted $p<0,05$ for $t$ test and Mann Whitney $U$ test process.

Results: In the measurements that compared the improvement of both groups, based on pre- and post-treatment evaluations; improvement in the experimental group was significantly higher in all of these parameters of ROM, VAS, TSK and ODI than in the control group $(p<0,05)$.

\begin{tabular}{|c|c|c|c|c|c|c|}
\hline Difference & & $\mathrm{N}$ & $\mathrm{D} \pm$ & SD & U & $\mathrm{p}$ \\
\hline Lumbal flexion angle & control & 20 & $10,70 \pm$ & 4,18 & 346,50 & $\underline{0,000^{*}}$ \\
\hline intervention & 20 & $\begin{array}{c}20,30 \\
\pm\end{array}$ & 7,25 & & & \\
\hline $\begin{array}{l}\text { Lumbal extantion } \\
\text { angle }\end{array}$ & $\begin{array}{c}\text { control } \\
\text { intervention }\end{array}$ & $\begin{array}{l}20 \\
20\end{array}$ & $\begin{array}{l}2,25 \pm \\
3,95 \pm\end{array}$ & $\begin{array}{l}1,65 \\
2,42\end{array}$ & 282,50 & $\underline{0,024^{\star}}$ \\
\hline VAS-rest & $\begin{array}{c}\text { control } \\
\text { intervention }\end{array}$ & $\begin{array}{l}20 \\
20\end{array}$ & $\begin{array}{l}-1,86 \pm \\
-3,37 \pm\end{array}$ & $\begin{array}{l}1,53 \\
2,26\end{array}$ & 109,50 & $\underline{0,014^{*}}$ \\
\hline VAS mobility & $\begin{array}{c}\text { control } \\
\text { intervention }\end{array}$ & $\begin{array}{l}20 \\
20\end{array}$ & $\begin{array}{l}-1,87 \pm \\
-3,87 \pm\end{array}$ & $\begin{array}{l}1,10 \\
1,47\end{array}$ & 48,00 & $\underline{0,000^{*}}$ \\
\hline TSK & $\begin{array}{c}\text { control } \\
\text { intervention }\end{array}$ & $\begin{array}{l}20 \\
20\end{array}$ & $\begin{array}{c}-5,55 \pm \\
-14,25 \\
\pm\end{array}$ & $\begin{array}{l}3,95 \\
5,89\end{array}$ & 46,00 & $\underline{0,000^{*}}$ \\
\hline ODI & $\begin{array}{c}\text { control } \\
\text { intervention }\end{array}$ & $\begin{array}{l}20 \\
20\end{array}$ & $\begin{array}{c}-18,07 \\
\pm \\
-30,89\end{array}$ & $\begin{array}{r}10,63 \\
16,51\end{array}$ & 69,00 & $\underline{0,000^{*}}$ \\
\hline
\end{tabular}

